\title{
PEMANFAATAN TANAMAN OBAT DALAM MENGATASI KELUHAN KESEHATAN PADA KELOMPOK TANI TEBU JATIROTO LUMAJANG
}

\author{
Zainal Abidin \\ (Universitas Jember, Fakultas Keperawatan, Program Studi D3 Keperawatan, \\ Email: zainalabidin@unej.ac.id)
}

\begin{abstract}
ABSTRAK
Salah satu negara kepulauan terbesar didunia adalah Indonesia yang terletak digaris katulistiwa yang beriklim tropis oleh karena itu memiliki banyak keanekaragaman flora dan fauna didalamnya, selain itu juga terdapat keanekaragaman hayati yang salah satunya ragam variasi tanaman herbal. Laporan penelitian ini bertujuan untuk mengidentifikasi pemanfaataan dan pengolahan tanaman obat dalam mengatasi keluhan kesehatan petani tebu di Jatiroto Lumajang Metode penelitian yang dipilih adalah penelitian deskriptif eksploratif. Pengambilan data dilakukan dengan cara survei eksploratif pada kelompok tani tebu Jatiroto Lumajang. Seluruh anggota kelompok tani tebu di Kecamatan Jatiroto kabupaten lumajang menjadi Populasi dalam penelitian ini, dengan sampel penelitian sejumlah 150 orang. Hasil penelitian menunjukkan bahwa jenis tanaman obat yang digunakan oleh Kelompok Tani Tebu di Jatiroto Lumajang adalah Tanaman Salam, Tanaman Sirih, Tanaman Jahe, Tanaman Temulawak, Tanaman Sirsak, Tanaman Kencur, dan Tanaman Kunyit. Jahe adalah tanaman yang paling banyak dimanfaatkan oleh responden yakni sebanyak 56 responden $(37,3 \%)$. Selain jahe, tanaman lain yang paling banyak dimanfaatkan adalah tanaman sirih sebanyak 29 responden $(19,3 \%)$ dan tanaman daun salam sebanyak 22 responden $(14,7 \%)$. Laporan penelitian ini dapat dijadikan sumber pembaca untuk menjadi salah satu sumber guna mengimplementasikan pemanfaatan tanaman obat dalam mengurangi keluhan kesehatan pada daerah-daerah lain yang dominan masyarakatnya bermata pencaharian sebagai petani.
\end{abstract}

Kata kunci: Tanaman Obat, Tanaman Herbal, Keluhan Kesehatan, Kelompok Tani

\section{ABSTRACT}

One of the largest archipelagic countries in the world is Indonesia, which is located in the tropical equator because it has a lot of diversity of flora and fauna in it, besides that there are also a variety of biodiversity which is available in a variety of herbal plants. This research report aims to identify the utilization and processing of medicinal plants in overcoming the health complaints of sugar cane farmers in Jatiroto Lumajang. The research method was descriptive exploratory research. Data retrieval was carried out by exploratory surveys of the Jatiroto Lumajang sugarcane farming group. The populations in this study were all members of the Jatiroto Lumajang Sugar Cane Farmer Group, with a sample of 
150 people. The results showed that the types of medicinal plants used by Sugar Cane Farmers in Jatiroto Lumajang were Salam Plants, Betel Plants, Ginger Plants, Curcuma Plants, Soursop Plants, Kencur Plants, and Turmeric Plants. Ginger is a plant that is most widely used by respondents as many as 56 respondents (37.3\%). In addition to ginger, other plants that are most widely used are betel veneers as many as 29 respondents (19.3\%) and bay leaves as many as 22 respondents (14.7\%). This research report can be used as a source of readers to become one of the sources to implement the use of medicinal plants in reducing health complaints in other regions which are predominantly community-based as farmers.

Keywords: Medicinal Plants, Herbs, Health Complaints, Farmer Groups

\section{PENDAHULUAN}

\section{Latar Belakang}

Salah satu negara kepulauan terbesar didunia adalah Indonesia yang terletak digaris katulistiwa yang beriklim tropis oleh karena itu memiliki banyak keanekaragaman flora dan fauna didalamnya, selain itu juga terdapat keanekaragaman hayati yang salah satunya ragam variasi tanaman herbal. Dizaman modern ini, masyarakat masih belum mengetahui manfaat kesehatan yang terkandung dalam tanaman herbal, masyarakat lebih mengenal pengobatan konfensional berbahan kimia atau obat yang didapatkan dari resep dokter, banyak contoh pemanfaatan tanaman herbal dizaman moderen ini seperti manfaat jeruk nipis untuk mengobati batuk karena mengandung fellandren dan sitral yang memiliki kandungan yang sama dengan obat batuk komix jeruk nipis, selain dapat meredakan batuk jeruk nipis juga dapat meredakan demam, contoh lainnya yang mungkin familiar dimasyarakat adalah penggunaan daun jambu biji untuk mengobati diare karena memiliki kandungan flavonoid yang terdapat di dalam obat diapet.

$$
\text { Itulah beberapa contoh }
$$
penggunaan tanaman herbal untuk mengobati beberapa penyakit ringan yang sering terjangkit dimasyarakat, selain berkhasiat manfaat lain dari tanaman herbal adalah dapat dengan mudah didapatkan, beberapa negara berkembang masih menggunakan tanaman herbal sebagai bahan dasar kosmetik, jamu, obat, spa dan juga bahan baku makanan maupun minuman. Sumber bahan baku obat tradisional adalah manfaat yang didapatkan dari tanaman obat selain itu dapat meningkatkan derajat kesehatan masyarakat dalam konteks peningkatan pembangunan kesehatan masyarakat indonesia dan masyarakat sendiri masih banyak yang mengkonsumsi pengobatan tradisional terutama di wilayah pedesaan.

Mahalnya pengobatan moderen dan efek samping yang didapatkan mengakibatkan masyarakat mulai beralih kepengobatan tradisional karena adanya kecenderungan kembali ke alam atau Back to Nature, dapat dilihat dari meningkatnya permintaan 
tanaman obat. Selain itu juga terdapat peningkatan pemanfaatan tanaman obat untuk bahan dasar atau keperluan industri seperti kosmetik, makanan dan minuman sehingga permintaan bahan baku makin tinggi.

Dari data kementrian perindustrian menunjukkan bahwa produk obat tradisional di Indonesia telah mengalami peningkatan dalam beberapa tahun terakhir, ditahun 2010 indonesia mencatat industri obat tradisional sebesar Rp 1,5 Triliun, namun ditahun 2013 meningkat menjadi 2,8 triliun atau 23,3\% (Kementrian pertanian, 2015), walau memiliki peluang yang cukup besar dalam pengelolaan dan budidaya tanaman obat ada beberapa kendala besar yang dihadapi indonesia yaitu dibidang produksi, ini disebabkan karena kegiatan budidaya tanaman obat yang tidak profesional karena masih sekitar 90\% bahan baku berasal dari tanaman liar, hutan maupun hasil dari pekarangan yang notabene tumbuh dengan sendirinya.

Minimnya bimbingan dan pelatihan pada petani menjadi penyebab ketidak mampuan petani dalam menjaga mutu dan kualitas tanaman obat serta minimnya penelitian ilmiah yang mengarah terhadap hasil-hasil industri tanaman kaitannya denga upaya peningkatan produk dan pemasaran, selain itu ada kendala besar lainnya berupa pembiayaan dan pengembangan usaha khususnya pada petani skala kecil.

Oleh karena itu supaya pengobatan herbal di indonesia menjadi pilihan dalam peningkatan derajat kesehatan masyarakat maka diperlukan penanganan secara konprenesif masalah, belum lagi masalah keamaanan produk yang juga menjadi fokus dari konsumsi penggunaan herbal dan tanaman obat karena banyak produk jamu herbal yang masih dicampur dengan bahan kimia obat (BKO) sehingga produk jamu khususnya jamu kemasan di Indonesia masih belum aman dikonsumsi dan akan sangat berbahaya jika dikonsumsi secara terus menerus, kontroling dari maraknya peredaran BKO memang masih sangat sulit namun penanganan yang paling efektif adalah keseadaran dari masyarakat untuk peduli terhadap jamu atau obat yang dikonsumsinya sehingga edukasi terhadap pentingnya manfaat akan produk pengobatan tradisional herbal masih dibutuhkan oleh masyarakat atau konsumen.

\section{Rumusan Masalah}

Bagaimana Pemanfaataan dan Pengolahan tanaman obat untuk mengatasi keluhan kesehatan petani Tebu di Jatiroto Lumajang?

\section{Tujuan Penelitian}

Penelitian ini bertujuan untuk mengidentifikasi Pemanfaataan dan Pengolahan tanaman obat untuk mengatasi keluhan kesehatan petani Tebu di Jatiroto Lumajang.

\section{METODE PENELITIAN}

Jenis penelitian merupakan penelitian deskriptif eksploratif. Metode penelitian ini yaitu survei eksploratif pada kelompok tani tebu Jatiroto Lumajang dengan menggunakan teknik wawancara kepada responden dan melalui penyebaran kuisioner. 


\section{HASIL PENELITIAN}

\section{Presentase Karakteristik Pendidikan pada Kelompok Tani} Tebu Jatiroto Lumajang

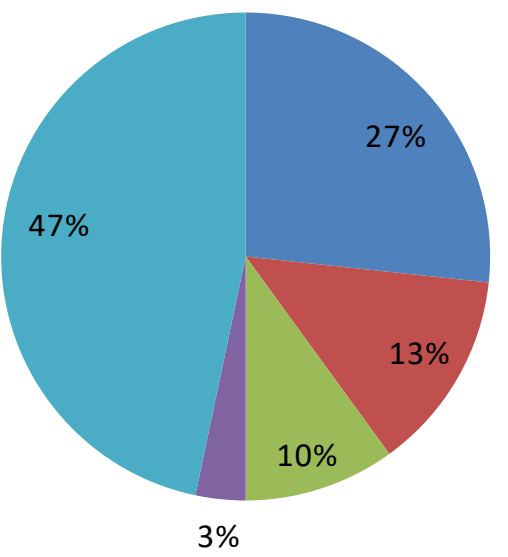

SD

SMP

SMA

Sarjana

Tidak Sekolah

$3 \%$

Gambar 1. Diagram Presentase Tingkat Pendidikan Responden

\section{Presentase Karakteristik Usia pada Kelompok Tani Tebu Jatiroto Lumajang}
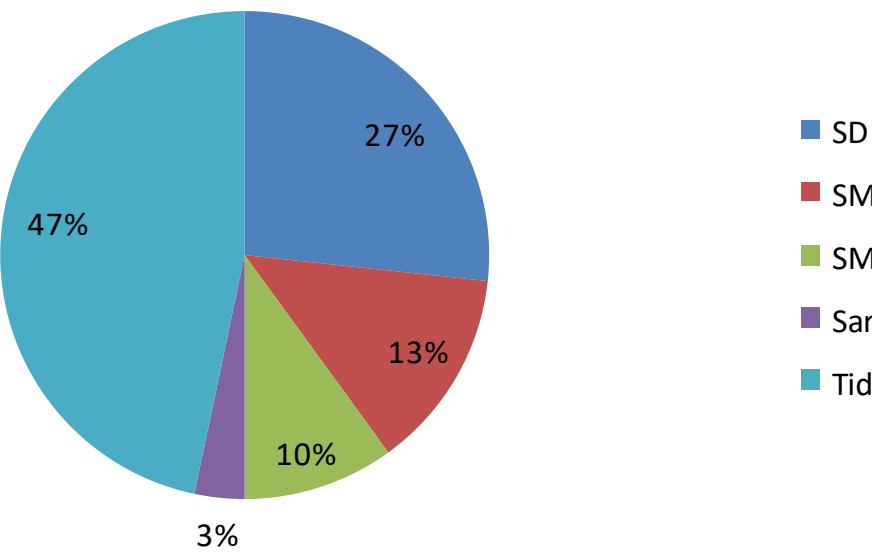

SMP

SMA

Sarjana

Tidak Sekolah

Gambar 2. Diagram Presentase Karakteristik Usia Responden 


\section{Presentase Karakteristik Jenis Kelamin pada Kelompok Tani Tebu Jatiroto Lumajang}

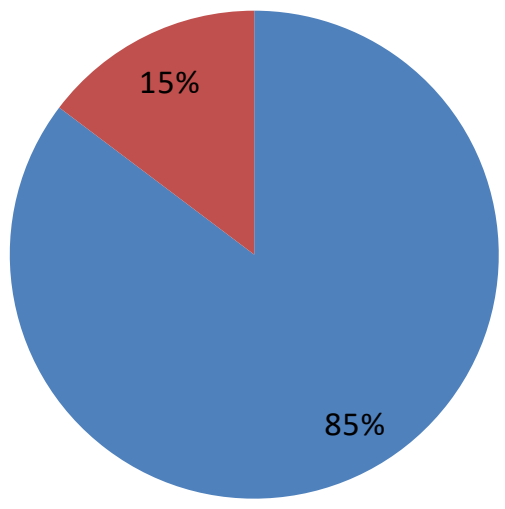

Gambar 3. Diagram Presentase Karakteristik Jenis Kelamin Responden

Tabel 1. Beberapa Tanaman yang Dimanfaat oleh Kelompok Tani Tebu di Jatiroto Lumajang

\begin{tabular}{|c|c|c|c|}
\hline No. & $\begin{array}{c}\text { Jenis Tanaman } \\
\text { Obat }\end{array}$ & $\begin{array}{c}\text { Manfaat dan Cara Pengolahan } \\
\text { Menurut Responden }\end{array}$ & $\begin{array}{l}\text { Jumlah Responden } \\
\text { Pengguna Tanaman } \\
\text { Obat (dalam \%) }\end{array}$ \\
\hline 1 & $\begin{array}{l}\text { Tanaman Salam } \\
\text { (Eugenia polyantha) }\end{array}$ & Pusing (rebus), linu (rebus, tumbuk) & $\begin{array}{c}22 \text { responden } \\
(14,7 \%)\end{array}$ \\
\hline 2 & $\begin{array}{l}\text { Tanaman Sirih (Piper } \\
\text { betle } L \text { ) }\end{array}$ & $\begin{array}{l}\text { Gatal (tumbuk), diare (tumbuk), batuk } \\
\text { (seduh), luka (tumbuk, seduh), gatal } \\
\text { (tumbuk) }\end{array}$ & $\begin{array}{l}29 \text { responden } \\
(19,3 \%)\end{array}$ \\
\hline 3 & $\begin{array}{l}\text { Tanaman Jahe } \\
\text { (Zingiber officinale) }\end{array}$ & $\begin{array}{l}\text { Batuk (seduh), diare (seduh), linu } \\
\text { (seduh), demam (seduh) }\end{array}$ & $\begin{array}{c}56 \text { responden } \\
(37,3 \%)\end{array}$ \\
\hline 4 & $\begin{array}{l}\text { Tanaman Temulawak } \\
\text { (Curcuma } \\
\text { zanthorrhiza) }\end{array}$ & Demam (seduh, rebus, tumbuk) & 8 responden $(5,3 \%)$ \\
\hline 5 & $\begin{array}{l}\text { Tanaman Sirsak } \\
\text { (Annona muricata) }\end{array}$ & $\begin{array}{l}\text { Linu (rebus, tumbuk), pusing (rebus, } \\
\text { seduh) }\end{array}$ & 10 responden $(6,7 \%)$ \\
\hline 6 & $\begin{array}{l}\text { Tanaman Kencur } \\
\text { (Kaempferia } \\
\text { galanga) }\end{array}$ & Diare (rebus, seduh) & 11 responden $(7,3 \%)$ \\
\hline 7 & $\begin{array}{l}\text { Tanaman Kunyit } \\
\text { (Curcuma domestica) }\end{array}$ & Gatal (rebus, seduh, tumbuk) & 14 responden $(9,3 \%)$ \\
\hline
\end{tabular}




\section{Presentase Pengguna Tanaman Obat oleh Kelompok Tani Tebu di Jatiroto Lumajang}

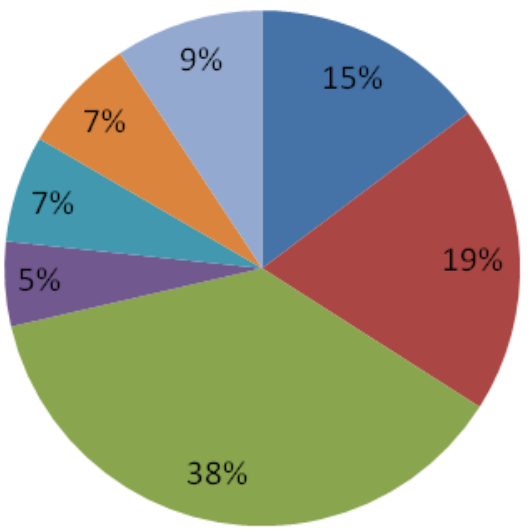

Tanaman Salam

Tanaman Sirih

- Tanaman Jahe

- Tanaman Temulawak

- Tanaman Sirsak

Tanaman Kencur

- Tanaman Kunyit

Gambar 4. Presentase Pengguna Tanaman Obat oleh Responden

\section{PEMBAHASAN}

Masyarakat Kelompok Tani Tebu Jatiroto di Kabupaten Lumajang ini tergolong masyarakat yang cukup maju dalam perekonomiannya. Ini terlihat dari rumah warga yang layak huni dan cukup bagus. Anggota Kelompok Tani Tebu Jatiroto ini masih menjunjung tinggi adat istirahat serta tradisi dari nenek moyangnya, misalnya masih memanfaatkan pekarangan rumah dalam mencukupi kebutuhan sehari-hari yang salah satunya adalah kebutuhan akan tanaman obat guna mengatasi keluhan kesehatan, baik pada Kelompok Tani Tebu Jatiroto maupun kerabatnya.

Interaksi antar anggota Kelompok Tani Tebu Jatiroto sanga erat karena hampir seluruh anggota Kelompok Tani Tebu Jatiroto merupakan saudara dan masih memiliki hubungan keluarga serta memiliki rumah dan ladang yang berdekatan. Selain itu, anggota juga rata-rata memiliki ladang garapan yang sama dengan saudaranya yang juga sebagai petani tebu.

Dari hasil wawancara diketahui bahwa seluruh responden biasanya memakai obat tradisional untuk mengatasi keluhan kesehatan mereka dalam kesehariannya. Menurut sebagian responden, mereka memakai obat tradisional untuk pengobatan karena mudah didapat (dari ladang), tidak memerlukan biaya, dan bisa diracik sendiri. Namun mereka juga mengonsumsi obat dari mantri atau dokter jika keluhan kesehatan tidak dapat disembuhkan total oleh tanaman obat yang mereka racik sendiri.

Tingkat pendidikan pada Kelompok Tani Tebu Jatiroto tergolong masih rendah. Hal ini didapat dari hasil wawancara dengan 150 responden anggota kelompok tani tersebut, yaitu tingkat 
pendidikan SD sebanyak 40 responden $(26,7 \%)$, SMP sebanyak 20 responden (13,3\%), SMA sebanyak 15 responden (10\%), Sarjana sebanyak 5 responden $(3,3 \%)$, dan responden yang tidak sekolah sebanyak 70 responden $(46,7 \%)$.

Berdasarkan diagram pada Gambar 1, didapatkan data bahwa tingkat pendidikan anggota Kelompok Tani Tebu Jatiroto Lumajang masih tergolong rendah. Meskipun demikian, mereka masih menjaga kelestarian tumbuhan yang ada di lingkungannya, termasuk tanaman obat yang biasa mereka manfaatkan. Hal ini membuktikan bahwa lahan terbuka disekitar rumah seperti pekarang adalah tempat yang cocok untuk untuk melakukan apotik hidup dengan menanam tanaman berkhasiat obat (Nurmayulis \& Hermita, 2015 dalam Dwisatyadini, 2017).

Karakteristik umur responden terdisi dari: masa remaja akhir (1725 tahun) sebanyak 24 responden (16\%), masa dewasa awal (26-35 tahun) sebanyak 30 responden (20\%), masa dewasa akhir (36-45 tahun) sebanyak 36 responden (24\%), masa lansia awal (46-55 tahun) sebanyak 45 responden (30\%), dan masa lansia akhir (56-65 tahun) sebanyak 15 responden (10\%).

Dari hasil wawancara dengan responden, data menunjukkan bahwa responden masih banyak yang memanfaatkan tanaman obat untuk mengatasi keluhan kesehatan mereka, terutama responden yang berada pada masa lansia awal yaitu sebanyak 45 responden (30\%). Hal ini membuktikan bahwa mereka masih mempercayai tumbuhan sebagai obat tradisional karena mereka sudah cukup informasi dari pengalaman orang lain maupun pengalaman sendiri dalam mengatasi keluhan kesehatannya. Berdasarkan data tersebut, dapat disimpulkan bahwa penggunaan tanaman obat semakin membaik dan mempercayai jika tanaman obat berkhasiat mengobati penyakit degeneratif ditandai dengan meningkatnya usia dan pengalaman (Dwisatyadini, 2017).

Responden berjenis kelamin laki-laki sebanyak 128 orang sedangkan responden berjenis kelamin perempuan sebanyak 22 orang. Berdasarkan hasil wawancara dengan anggota Kelompok Tani Tebu Jatiroto, diketahui bahwa hubungan jenis kelamin dengan pemanfaatan tanaman obat dalam mengatasi keluhan kesehatan adalah laki-laki lebih mendominasi daripada perempuan karena mayoritas lakilaki yang meng-nggarap lahan tebu dan didapatkan data dari hasil wawancara bahwa laki-laki memiliki peranan yang sangat penting dalam pemanfaatan tanaman obat karena laki-laki lebih sering mencari tanaman obat dari pada perempuan sehingga pengetahuan laki-laki lebih banyak daripada perempuan. Namun, hal itu tidak menjadi alasan bagi petani perempuan untuk tidak tahu informasi mengenai tanaman obat karena dari hasil wawancara juga didapatkan data bahwa dominan perempuan yang mengolah tanaman obat di rumah (petani perempuan atau istri petani laki-laki).

Hasil penelitian menunjukkan Kelompok Tani Tebu di Jatiroto Lumajang, diperoleh data bahwa 
terdapat 7 tanaman yang digunakan oleh 150 responden untuk mengatasi keluhan penyakit mereka. Berdasarkan Tabel 1 dan Gambar 4 diatas, didapatkan data bahwa jahe (Zingiber officinale) adalah tumbuhan yang paling banyak dimanfaatkan oleh responden yakni sebanyak 56 responden atau 37,3\% dari 150 responden. Didapatkan data wawancara bahwa dominan responden melilih memanfaatkan jahe karena lebih mudah diolah, mudah didapatkan, dan keluhan yang dirasakan memang sesuai dengan manfaat jahe. Selain jahe, tanaman lain yang paling banyak dimanfaatkan adalah tanaman sirih sebanyak 29 responden atau 19,3\% dari 150 responden dan tanaman daun salam sebanyak 22 responden atau $14,7 \%$ dari 150 responden.

Menurut responden, tanaman salam dapat dimanfaatkan untuk mengatasi keluhan kesehatan berupa pusing karena hipertensi dengan cara pengolahan direbus. Hal ini sesuai dengan pernyataan Agoes (2010) dalam Yulianti, Setyaningsih, \& Suryaningsih (2014), Syzygium polyanthum atau biasa disebut daun Salam merupakan nama pohon yang menghasilkan daun rempah yang sering digunakan untuk masakan tradisional indoensia. Daun ini juga bermanfaat untuk terapi hipertensi. Tidak sulit untuk mendapatkan daun salam karena sering dijumpai dan dikenal oleh masyarakat serta aman dikonsumsi Makanan tradisional indonesia sering menggunakan daun salam sebagai pelengkap masakan, di Asia tenggara daun ini banyak tumbuh menyebar, dan banyak terdapat dilingkungan disekitar pekarangan rumah, selain bermanfaat untuk bumbu masakan, penggunaan daun salam juga mempunyai manfaat bagi kesehatan antara lain untuk mengobati radang lambung atau gastritis, DM, diare, pruritus, hipertensi dan mabuk akibat mengkonsumsi minuman keras. Terdapat tiga komponen daun salam yaitu minyak atsiri berfungsi sebagai pengharum dan penyedap sehingga menengkan pikiran serta dapat menurunkan sekresi hormon stress, daun salam mengandung tanin yang dapat merelaksasikan otot arteri yang bermanfaat bagi pasien hipertensi dalam menurunkan tekanan darah, kandungan flavonoid juga sebagai pencegahan hipertensi dengan cara pembentukan angiotensin II dengan cara mengambat aktivitas ACE sebagai inhibitor.

Menurut responden, tanaman salam dapat dimanfaatkan untuk mengatasi keluhan berupa linu karena asam urat yang tinggi dengan cara pengolahan direbus atau ditumbuk. Pernyataan ini dikuatkan dari Hasil uji praklinik antihiperurisemia yang dilakukan oleh Muhtadi,dkk (2010) didapat kombinasi ekstrak daun salam dan Nigella sativa linn atau biasa disebut jinten hitam dengan dosis tunggal $200 \mathrm{mg} / \mathrm{kgBB}$ didapatkan hasil penurunan kadar asam urat dalam darah,

Penurunan kadar asam urat juga dibuktikan dengan penggunaan mencit putih jantan Balbc yaitu dengan menginduksi potassium oksonat dengan hasil prosentase 
penurunan kadar asam urang $79,35 \%, \quad 61,29 \%$, dan 72,90\%, walaupun masih jauh dari penurunan yang ditunjukan oleh obat allopurinol sebesar 93,55\% namun mencit putih jantan bisa dijadikan alternatif penurun asam urat dalam darah, hasil ekstraksi air daun salam dapat dijadikan acuan untuk kadar fenolat total sebesar $1,08 \%$ dan total flavonoid mempunyai kadar $0,196 \%$, sedangkan hasil ekstrak air jinten hitam kadar fenolat total sebesar $0,66 \%$ untuk kadar flavonoid total sebesar $0,40 \%$. ekstrak jinten hitam memiliki senyawa identitas yaitu luteolin, sedangkan ekstrak daun salam adalah flouretin. Perbedaaan potensi penurunan kadar asam urat terjadi karena perbedaan senyawa aktif tersebut sehingga dari hasil yang diperoleh senyawa flueoretin lebih poten dari ekstrak daun salam (Harsimah \& Chusniatun, 2016).

Menurut responden, selain daun salam, tanaman sirih juga dimanfaatkan untuk berbagai keluhan kesehatan seperti: gatal, diare, batuk, luka. Salep ekstraketanol dari daun sirih bermanfaat untuk proses penyembuhan luka dan telah terbukti pada penelitian yang diuji cobakan pada Rattus norvegicus atau lebih dikenal tikus putih jantan manfaat lain dari salep daun sirih adalah menjadi alternatif terapi untuk penyembuhan luka (Fannani \& Nugroho, 2014). Daun sirih juga memiliki fungsi seperti hanya antibiotik karena memiliki fungsi sebagai antiseptik karena memiliki zat saponin dan tannin sebagai antiseptik jika ada luka permukaan, cara kerjanya yaitu bakteriostatik atau mencegah perkembangbiakan bakteri pada luka dikulit yang terinfeksi, mukosa dan mengobati infeksi pada luka. Penelitian ini menggunakan lumatan daun sirih pada luka insisi (Latuheru, W, \& Posangi, 2013).

Manfaat lain dari daun sirih adalah untuk mengobati bau badan tak sedap, sariawan, bau mulut, mimisan, bisul, imunosupresan, jerawat, pelindung hati, mencegah produksi air susu berlebihan, mengobati iritasi pada mata, gatalgatal dan koreng pada kulit, pada wanita dapat mengobati keputihan, menghentikan batuh meluruhkan kentut, mengurangi peradangan menghilangkan gatal, menahan pendarahan, mempercepat proses menyembuhkan luka pada kulit, dan mencegah diare . Bakteri yang umum dikenal dimasyarakatn saat ini adalah bakteri Exherichia coli. Baktei Echerichia coli merupakan bakteri golongan colifor $\mathrm{m}$, bakteri berdarah panas dan hidup dikolon manusia ini. Baktei Escherichia coli dalam jurnlah kecil atau sedikit dapat memberikan keuntungan karena dapat berfungsi untuk mensintesa vitamin $\mathrm{B}$, dan vitamin $\mathrm{K}$ (tapi dalam jumlah yang besar atau banyak dapat merugikan karena dapat menginfeksi usus sehingga menjadi penyebab penyakit diare).

Daun sirih mempunyai beberapa manfaat yaitu sebagai penghambat pertumbuhan mikroorganisme (antiseptik), melindungi sel tubuh (antioksidasi) dan pembasmi jamur (fungisida). Ektrak Minyak atsiri mampu mengatasi beberapa bakteri gram positif dan gram negatif hal ini disebabkan oleh karena minyak atsiri 
memiliki daya pembunuh bakteri hingga lima kali lipat dari phenol biasa dari kandungan kavikol yang dimilikinya dan juga memiliki bau khas daun sirih (Saraswati, 2011).

Daun sirih juga bisa mengobati pertusis atau batuk rejan dengan cara 7 lembar daun sirih dan gula batu. Setelah itu direbus dengan 1 gelas air hingga tersisa $1 / 2$ gelas air. kemudian diminum 3 kali sehari 1 sendok. makan. Untuk pengobatan disentri, sirih dicampur gambir dan kapur ditumbuk halus dan diseduh dengan air. Ramuan tersebut ditumbuk dan diseduh dengan air, ramuan tersebut diminum 3 kali sehari 1 sendok makan(Ningtias, Asyiah, \& Pujiastuti, 2014).

Tanaman jahe juga dimanfaatkan oleh responden untuk mengatasi keluhan kesehatan berupa: batuk, diare, linu, dan demam.Responden memanfaatkan tanaman jahe untuk diare. Berdasarkan penelitian dari Pamungkas \& Dewi (2013), menyebutkan bahwa dari ketiga jenis jahe yang ada, jahe merah memiliki kandungan atsiri dan oleoresin-nya paling tinggi dan lebih banyak digunakan sebagai obat dibandingkan dengan jenis jahe yang lain. Dari hasil penelitian menunjukkan adanya bahan aktif jahe (gingerol) yang dapat menghambat proses pertumbuhan bakteri. Escherichia coli adalah bakteri gram negatif yang berbentuk batang dan termasuk dalam family Enterobacteriaceae. Pada tingkat dunia, ETEC (Escherichia coli entero hemoragik) telah mengakibatkan lebih dari 600 juta kasus diare dalam setahun. Menurut responden, tanaman jahe dapat dimanfaatkan dengan cara diseduh. Namun cara penggunaan yang paling tepat adalah direbus kemudian meminum air rebusan. Hal ini sesuai dengan teori yang ada dalam Modul Tanaman Obat Herba Berakar Rimpang (2012), yaitu jahe dimanfaatkan sebagai minuman karena dengan meminum secangkir air rebusan rimpang jahe 3-10 gram. Bermanfaat untuk memberikan efek aroma terapi yang menyegarkan, hangat, pedas, akan lebih nikmat jika diminum ketika hangat, uapnya juga meringankan gejala hidung tersumbat akibat flu. Di Jawa terkenal minuman jahe seperti wedang ronde, bandrek, wedang jahe, dengan tambahan rempah lain, air jeruk nipis, susu, atau madu (Tim TPC, 2012).

Responden memanfaatkan jahe untuk mengatasi keluhan kesehatan berupa linu dengan cara diseduh. Keluhan kesehatan linu mendominasi karena usia lanjut sehingga memiliki risiko tinggi untuk terjadinya asam urat tidak belum terdeteksi atau belum dilakukan tes/cek lab. Pengolahan jahe untuk mengatasi linu kurang tepat jika diolah dengan cara diseduh. Menurut Tim TPC Research and Community Service Institution (2012), pengolahan jahe dengan cara menumbuk dua jarisampai halus dengan ditambah air secukupnya sampai menjadi adonan dan setelah itu ditempelkan pada bagian yang sakit.

Untuk mengatasi keluhan kesehatan berupa demam, seduhan jahe juga dimanfaatkan oleh responden menurut Winarti pada tahun 2013 berpendapat bahwa banyak produk jahe yang digunakan sebagai karminatif atau pencegah 
perut kembung dan meredakan demam dengan dibuat menjadi teh, namun di Cina digunakan sebagai tonik.

\section{SIMPULAN}

Jenis tanaman obat yang digunakan oleh Kelompok Tani Tebu di Jatiroto Lumajang adalah Tanaman Salam (Eugenia polyantha), Tanaman Sirih (Piper betle L), Tanaman Jahe (Zingiber officinale), Tanaman Temulawak (Curcuma zanthorrhiza), Tanaman Sirsak (Annona muricata), Tanaman Kencur (Kaempferia galanga), dan Tanaman Kunyit (Curcuma domestica). Jahe (Zingiber officinale) adalah tumbuhan yang paling banyak dimanfaatkan oleh responden yakni sebanyak 56 responden atau 37,3\% dari 150 responden. Selain jahe, tanaman lain yang paling banyak dimanfaatkan adalah tanaman sirih sebanyak 29 responden atau 19,3\% dari 150 responden dan tanaman daun salam sebanyak 22 responden atau $14,7 \%$ dari 150 responden.

\section{SARAN}

Laporan penelitian ini dapat dijadikan sumber pembaca untuk menjadi salah satu sumber guna mengimplementasikan pemanfaatan tanaman obat untuk mengurangi keluhan kesehatan. Untuk melengkapi informasi tentang penggunan tanaman obat untuk mengurangi keluhan kesehatan pada petani, dapat dilakukan penelitian pada daerah-daerah lain yang dominan masyarakatnya bermata pencaharian sebagai petani.

\section{DAFTAR PUSTAKA}

Agoes, A. (2013). Tanaman Obat Indonesia - Profil Balai Besar Penelitian dan Pengembangan Tanaman. Jakarta: Salemba Medika.

Dewi, I. (2012). Resep dan Khasiat Jamu Tradisional Nusantara Pembelajaran Pengurangan Risiko Bencana pada Kurikulum 2013. Surabaya: Penerbit Liris.

Dwisatyadini, M. (2017). Pemanfaatan Tanaman Obat untuk Pencegahan dan Pengobatan Penyakit Degeneratif. Optimalisasi Peran Sains dan Teknologi untuk Mewujudkan Smart City 2, 237-270.

Fannani, M., \& Nugroho, T. (2014). Pengaruh Salep Ekstrak Etanol Daun Sirih (Piper betle) terhadap Penyembuhan Luka Iris pada Tikus Putih Jantan (Rattus norvegicus). JKKI Vol. 6 No. 1, 19-26.

Harnilawati. (2013). Konsep dan Proses Keperawatan Keluarga. Sulawesi Selatan: Pustaka AsSalam.

Harsimah, K., \& Chusniatun. (2016). Pemanfaatan Daun Salam Sebagai Obat Herbal dan Rempah Penyedap Makanan. WARTA LPM, Vol. 19 No. 2 , 111.

Hesti Mulyani, S. H. (2016). Tumbuhan Herbal sebagai Jamu Pengobatan Tradisional 
terhadap Penyakit dalam Serat Primbon Jampi Jawi Jilid 1. Jurnal Penelitian Humaniora Vol 21 No 2, 75.

Latuheru, J. O., W, J. T., \& Posangi, J. (2013). Efek Daun Sirih (Piper Betle L.) Terhadap Penyembuhan Luka Insisi Kulit Kelinci (Oryctolagus cuniculus). Jurnal e-Biomedik (eBM), Volume 1, Nomor 2, , 803.

Mahdi, I. (2015). Inventarisasi Tumbuhan yang Digunakan pada Ritual Adat di Desa Tindang Kecamatan Bontonompo Selatan Kabupaten Gowa. Makassar: Universitas Islam Negeri Alauddin Makassar.

Mayanti, A. (2013). Pengaruh Larutan Ekstrak Daun Sirih (Piper Betle L) terhadap Perubahan Warna Basis Resin Akrilik Heat Sured. Makassar: Universitas Hasanuddin.

Ningtias, A. F., Asyiah, I. N., \& Pujiastuti. (2014). Manfaat Daun Sirih (Piper betle L.) Sebagai Obat Tradisional Penyakit Dalam di Kecamatan Kalianget Kabupaten Sumenep Madura (Benefits of Betel Leaf (Piper betle L.) As Traditional Medicine for Internal Disease in Kalianget District Sumenep Regency Madura). Artikel Ilmiah Hasil Penelitian Mahasiswa, 3.

Pamungkas, Y. P., \& Dewi, M. (2013). Efek Anti Bakteri Perasan Jahe Merah terhadap
Bakteri Escherichia coli Secara In Vitro. Jurnal Farmatesis Vol 2 No2 , 47.

Purwanto, B. (2014). Buku Ajar Ilmu Keperawatan Berbasis Herbal. Jogjakarta: D-Medika.

Restiani, K. (2009). Uji Efek Sediaan Serbuk Instan Rimpang Jahe (Zingiber onfficianale Roscoe) sebagai Tonikum Terhadap Mencit Jantan Galur Swiss Webster. Surakarta: Universitas Muhammadiyah.

Rusnoto, N., Cholifah, \& Retnosari, I. (2015). Pemberian Kompres Hangat Memakai Jahe Untuk Meringankan Skala Nyeri Pada Pasien Asam Urat Di Desa Kedungwungu Kecamatan Tegowanu Kabupaten Grobogan. JIKK VOL. 6 NO. 1 , 33-37.

Saraswati, D. (2011). Pengaruh Konsentrasi Ekstrak Daun Sirih Terhadap Daya Hambat Eschericha Coli. Jurnal Health \& Sport Vol 3 Nomor 2 , 331338.

Setiadi. (2007). Konsep dan Penulitan Riset Keperawatan. Yogyakarta: Graha Ilmu.

Susila, A., Sumarno, \& Dewi, D. (2014). Efek Ekstrak Jahe (Zingiber officinale Rosc.) terhadap Penurunan Tanda Inflamasi Eritema pada Tikus Putih (Rattus novergicus) Galur Wistar dengan Luka Bakar Derajat II. Majalah Kesehatan FKUB Volume 1 Nomer 4 Desember 2014, 214222. 
Tim TPC. (2012). Tanaman Obat Herba Berakar Rimpang. Bogor: BOGOR AGRICULTURAL UNIVERSITY.

Winarti, H. \&. (2013). Kandungan Bahan Aktif Jahe dan Pemanfaatannya dalam Bidang Kesehatan. Bogor: Balai Besar Penelitian Dan Pengembangan
Pascapanen Pertanian.

Yulianti, T. S., Setyaningsih, R., \& Suryaningsih, M. (2014). Pengaruh Air Rebusan Daun Salam Terhadap Penurunan Tekanan Darah Pada Penderita Hipertensi Di Dukuh Jangkung Rejo Nogosari Boyolali. JIK. Vol. 2 No. 2 , 39-40. 